\title{
PENYEBARAN TAREKAT SAMMANIYAH DI KALIMANTAN SELATAN OLEH K.H.MUHAMMAD ZAINI GHANI
}

\author{
Ahmad Zakki Mubarak*
}

\begin{abstract}
This paper describes about the al-Sammaniyah tarekat which was popularized by K.H. Mubammad Zaini. He is known as a scholar who became a role model of Banjar society. K.H. Muhammad Zaini is a charismatic cleric (ulama). His popularity is not only in the Kalimantan region, but to foreign countries. Pilgrims who follow the teachings amount to dozens, even thousands of people. He is known for its breadth of his knowledge, moral virtue, and generosity. In delivering his message, he has a quiet way of speaking, so that the people who listens him feel cool, calm and solemn.
\end{abstract}

Kata Kunci : Tarekat, Manaqib, dan Ulama.

\section{Pendahuluan}

K.H. Muhammad Zaini Ghani adalah salah satu tokoh fenomenal di tanah Banjar ini. Beliau telah berdakwah untuk menyebarkan Islam secara intensif di wilayah ini. Dalam upaya dakwahnya tersebut, beliau menggunakan berbagai media dalam dakwahnya di antaranya adalah tarekat Sammaniyah yang cukup popular bagi masyarakat Banjar hingga saat ini.

Muhammad Zaini Ghani akrab dipanggil dengan sebutan Guru Ijai atau Abah Guru merupakan seorang ulama kharismatik yang ada di Kalimantan Selatan dan beliau merupakan keturunan dari Syekh Muhammad Arsyad AlBanjari. Nama lengkap beliau adalah Kyai Haji Muhammad Zaini Ghani bin Abdul Ghani bin H. Abdullah bin Mufti H. Muhammad Khalid bin Khalifah H. Hasanuddin bin Syekh Muhammad Arsyad Al-Banjari. Dalam kitab beliau sering dicantumkan nama beliau dengan sebutan Abû Muhammad Amîn Badalî. Ibu beliau bernama Hj. Masliah binti H. Mulya. Beliau dilahirkan pada malam Rabu, 27 Muharram $1361 \mathrm{H}$ atau bertepatan dengan 11 Pebruari 1942 M di Martapura. K.H. Muhammad Zaini Ghani memilik 4 orang isteri dan

\footnotetext{
*Dosen tetap STAI Al-Falah Banjarbaru.
} 
tingggal bersama mereka. Beliau mempunyai 2 orang anak, yaitu Muhammad Amin Badaly dan Ahmad Hafy Badaly, dan Sayyid Muhammad anak dari Sayyid Ahdal. ${ }^{1}$

Sejak kecilnya beliau dididik oleh kedua orang tuanya dan neneknya yang bernama Salbiyah. Di masa itu, kepada beliau sudah mulai ditanamkan pendidikan tauhid, akhlak dan membaca al-Qur'an. ${ }^{2}$ Meskipun kehidupan kedua orang tua beliau dalam keadaan ekonomi yang lemah, namun mereka selalu memperhatikan untuk membantu dan meringankan beban guru yang mengajar anak mereka membaca al-Qur'an. Misalnya setiap malam Guru Ijai selalu membawa bekal botol kecil yang berisi minyak tanah untuk diberikan kepada Guru Hasan Keraton yang mengajar al-Qur'an.

Pada usia 7 tahun Guru Ijai sudah mulai belajar di Madrasah Darussalam Kampung Keraton Martapura sampai usia kira-kira 9 tahun. Setelah itu, beliau melanjutkan studi ke Madrasah Darussalam Pesayangan Martapura, sampai selesai selama sekitar 20 tahun. Beliau kemudian melanjutkan pendidikannya di Bangil, Jawa Timur. Sekembalinya dari Bangil beliau langsung diangkat menjadi guru di Pondok Pesantren Darussalam Martapura sekitar 5 tahun lamanya dan beliau juga mengajar santri-santri di rumah. ${ }^{3}$

Para guru yang mempengaruhi beliau di masa pendidikan adalah Guru Abdul Mu'az, Sulaiman, Muhammad Zein, H. Abd. Hamid Husin, H Mahalli, H. Rafi'i, Syahran, H. Husin Dakhlan, dan H. Salman Yusuf, Tuan Guru H. Sya'rani 'Arif, H. Husin Qadri, H. Salim Ma'ruf, H. Seman Mulya dan H. Salman Jalil. Guru-guru beliau di bidang tajwid adalah H. Sya'rani 'Arif, AlHafizh H. Nashrun Thahir dan H. Aini Kandangan. Selain itu, beliau juga memiliki guru khusus, yaitu H. Muhammad Syarwani Abdan dan Syekh Sayyid Muhammad Amîn Kutbî. ${ }^{4}$ Guru beliau di bidang rohani adalah Ali Junaidi Berau dan al-'Allamah H. Muhammad Syarwani Abdan. Kemudian H. Muhammad Syarwani Abdan menyerahkannya kepada Kyai Falak, dan Kyai Falak menyerahkannya kepada Syekh Muhammad Amîn Kutbî, kemudian beliau menyerahkannya kepada Syekh Muhammad Arsyad al-Banjari yang selanjutnya langsung dipimpin oleh Rasulullah saw. Kemudian atas petunjuk al-

${ }^{1}$ Syahriansyah, dkk., Profil Tarikat ..., h. 86.

${ }^{2}$ Syahriansyah, dkk., Ulama Banjar dan Karya-Karyanya, K.H. Abdul Hamid Karim, K.H. Zaini Gani dan K.H. Muhammad Bakheit,(Banjarmasin: Puslit IAIN Antasari, 2009), h. 17.

${ }^{3}$ Syahriansyah, dkk., Ulama Banjar ..., h. 17.

${ }^{4}$ Syahriansyah, dkk., Profil Tarikat di Kalimantan Selatan, (Banjarmasin: Antasari Press, 2009), h. 85. 
'Allamah 'Alî Junaidî Berau, beliau dianjurkan untuk belajar kepada H. Muhammad Gadung Rantau bin H. Salmân Farisi bin H. Qadhi H. Mahmud bin Asiah binti Syekh Muhammad Arsyad al-Banjari mengenai Nur Muhammad. Sedangkan sanad-sanad dalam berbagai bidang ilmu dan thariqat beliau terima dari beberapa guru, yaitu: al-'Alim al-'Allâmah al-'Arif bi Allâh alQuthb al-Sayyid Muhammad Amîn al-Kutbî, al-'Alim al-'Allâmah al-Quthb alSyaikh al-Sayyid 'Abd al-Qâdir al-Bâr, al-'Alim al-'Allâmah al-Sayyid Muhammad bin 'Alwî al-Mâlikî, al-'Alim al-'Allâmah al-Syaikh Hasan Masysyâth, al-'Alim al-'Allâmah al-Syaikh Muhammad Yâsîn Pâdâng, al-'Alim al-'Allâmah Kyai Falak (Bogor), dan al-'Alim al-'Allâmah al-Syaikh Ismâ'il Yamânî.

Guru ijai juga telah membuka pengajian agama atau majelis ta'lim yang bertempat di rumah beliau sendiri di Keraton Martapura sekitar tahun 1970, yang pada awalnya bergabung dengan pengajian agama asuhan K.H. Muhammad Salman Mulya yang dikenal dengan sebutan Guru Tuha. Pada tahun 1988 lokasi pengaiian dipindahkan dari Keraton ke Komplek Sekumpul. Sejak saat itu kegiatan pengajian bertambah ramai dikunjungi oleh segenap lapisan masyarakat, baik pria maupun wanita, dengan latar belakang pendidikan dan profesi yang tidak sama. Mereka yang menuntut ilmu ke Komplek Sekumpul bukan saja berasal dari Kalimantan Selatan, bahkan dari luar wilayah Kalimantan Selatan. ${ }^{5}$

Di Komplek Sekumpul telah dibangun sebuah mushalla yang bernama Ar-Raudhah berukuran cukup besar dan megah, serta halamannya cukup luas, sehingga dapat menampung puluhan ribu jamaah yang datang ke sana. Rumah tempat tinggal beliau dibangun di sebelah kiri berdampingan dengan mushalla tersebut, dan akhirya Komplek Sekumpul semakin ramai, karena banyak perumahan dibangun di sekitarnya terutama oleh para murid Guru Ijai.

Selain dari kegiatan majelis ta'lim di atas, guru Ijai juga selalu sibuk melayani masyarakat dari berbagai kalangan, orang awam, ulama, umara bahkan artis yang memerlukan bimbingan, keilmuan, nasihat atau pertimbanganpertimbangan keagamaan dan lain-lain. Di antara tamu beliau, ada juga yang datang dari luar negeri, seperti dari Brunai Darussalam, Singapura, Malaysia, Hadhralmaut dan lain-lain.

Sebelum akhir hayatnya K. H. Muhammad Zaini Ghani memperoleh cobaan yang begitu berat, karena penyakit yang dideritanya. Beliau sempat dibawa berobat di rumah sakit Singapura untuk mendapatkan perawatan

${ }^{5}$ Abdurrahman Jaferi, 2000, h. 22-23 
intensif. Namun karena kondisi fisik beliau sudah menurun, akhirnya beliau dibawa pulang ke Banjarmasin pada hari Selasa tanggal 4 Rajab 1426 H (9 Agustus 2005) dan tiba di Banjarmasin pada hari Selasa malam pukul 20.30 wita (5 Rajab $1426 \mathrm{H}$ ). Beliau meninggal dunia pada pukul 05.10 wita waktu Shubuh hari Rabu 5 Rajab 1426 H (10 Agustus 2005 M).

Tulisan-tulisan beliau yang telah dikenal terdiri dari Risâlah Mubârakah, Manaqib al-Syaikh al-Sayyid Muhammad bin 'Abd al-Karîm al-Qâdirî al-Hasanî al-Sammân al-Madanî, al-Risâlah al-Nurâniyyah fî Syarh al-Tawassulât alSammaniyah, Nubdzah min Manâqib al-Imâm al-Masyhûr bi al-Ustâdz alA'zham Muhammad bin 'Ali Bâ 'alawî, al-Imdâd fî Aurâd Ahl al-Widâd. Namun dari semua karya tersebut, ada tiga kitab dari karya K.H. Muhammad Zaini Ghani yang penulis temukan.

Kelima kitab yang ditulis guru Ijai tersebut adalah karya orisinil karangan beliau. ${ }^{6}$ Akan tetapi hanya tiga kitab yang sempat dipublikasikan beliau secara luas yakni Manaqib al-Syaikh al-Sayyid Muhammad bin 'Abd al-Karîm al-Qâdirî al-Hasanî al-Sammân al-Madanî, al-Risâlah al-Nurâniyyah fî Syarh alTawassulât al-Sammâniyah, dan al-Imdâd fî Aurâd Ahl al-Widâd. ${ }^{7}$

\section{Tarekat Sammaniyah di Kalimantan Selatan}

\section{Asal-Usul dan Perkembangan}

Nama pendiri tarekat Sammaniyah adalah Muhammad bin Abd al-Karim al-Qadari al-Hasani al-Samman al-Madani, dilahirkan di Madinah pada tahun 1132H/1719M dan meninggal di kota yang sama pada tahun 1189 H/1776 M kemudian dimakamkan di Baqi' dekat kubur para isteri Rasulullah saw. Ia melewatkan hidupnya di Madinah. Dia tinggal di dalam rumah bersejarah milik Abu Bakar al-Shiddiq. Al-Samman mengajar di Madrasah Sanjariyah, yang didatangi para muridnya dari negeri-negeri yang jauh. Ia diriwayatkan pernah berpergian ke Yaman dan Mesir pada tahun 1174H/1760 M. untuk mendirikan cabang-cabang tarekat Sammaniyah dan mengajar murid-muridnya mengenai zikir Sammaniyah. ${ }^{8}$

\section{Zaini Ghani}

${ }^{6}$ Wawancara Sahriansyah, dkk., dengan Abu Daudi, penulis manakib K.H. Muhammad

${ }^{7}$ Wawancara dilakukan oleh Syahriansyah, dkk., dengan Abu Daudi, Rabu tanggal 18 November 2009, dan lihat pula Syahriansyah, dkk., Ulama Banjar ..., h. 28.

${ }^{8}$ Azyumardi Azra, Jaringan Ulama Timur Tengah dan Kepulauan Nusantara Abad XVII dan XVIII, (Bandung: Mizan, 1994), h. 138. 
Al-Samman mempelajari berbagai tarekat dengan guru-guru yang tersohor pada zamannya. Namun al-Samman bukan ahli tarekat saja, ia juga mempelajari ilmu Islam lainnya. Suatu sumber Arab hampir sezaman dengannya, Sulaiman al-Ahdal dalam bukunya al-Nafs al-Yamani, menyebut lima gurunya yang kesemuanya merupakan ulama fikih terkenal, yaitu: Muhammad al-Daqaaq, Sayyid Ali al-Attar, Ali al-Kurdi, Abd al-Wahhab al-Tantawi dan Sa'id Hillal al-Makki. Gurunya di bidang tasawuf dan tauhid adalah Mustafa bin Kamal al-Din al-Bakri, pengarang produktif dan Syekh tarekat Khalwatiyyah dari Damaskus, yang pernah menetap di Madinah dan wafat di Kairo pada tahun 1749 M. Menurut beberapa sumber, al-Samman semasa kunjungannya ke Mesir (tahun 1760) juga pernah belajar kepada dua guru Khalwatiyah lainnya, Muhammad bin Salim al-Hifnawi dan Mahmud al-Kurdi, tetapi pengaruh keduanya tidak terlihat dalam karya-karya al-Samman. ${ }^{9}$

Al-Samman sering dihubungkan dengan Mustafa al-Bakri, seorang guru terkemuka dari tarekat Khalwatiyyah. Hubungannya dengan al-Bakri membuat sarjana seperti de Jong mengira, bahwa tarekat Sammaniyah pada dasarnya adalah cabang tarekat Khalwatiyah yang mengalami hanya sedikit perubahan doktrinal dari tarekat induknya. ${ }^{10}$ Dalam sejarahnya al-Samman juga memasuki tarekat Naqsabandiyyah dan tarekat Qadiriyyah. Oleh karena itu, orang sezamannya sering menyebutnya Muhammad bin Abd al-Karim al-Qadiri alSamman.

Syekh lain yang sangat berpengaruh terhadap ajaran dan praktik-praktik Sammaniyah (walaupun al-Samman tidak bertemu langsung dengannya), adalah Abdul Ghani al-Nablusi (w. $1143 \mathrm{H} / 1731 \mathrm{M}$ ), salah seorang guru Mustafa al-Bakri, tokoh besar tarekat Naqsabandiyah dan pengarang yang sangat produktif, pembela Ibnu Arabi dan Abd al-Karim al-Jilli.

Tarekat keempat yang diambil al-Samman adalah Syazaliyyah, yang mewakili tradisi tasawuf Maghrib dan terkenal dengan biz̧b-biz̧bnya. ${ }^{11}$ Dengan demikian, tarekat Sammaniyah jelas merupakan gabungan dari berbagai tarekat, di mana Al-Sammamn berafiliasi kepadanya, yaitu Khalwatiyah, Qadariyah, Naqsabandiyah dan Syadzaliyah.

Dalam kitab Siyar al-Salikin Abd Samad menyebutkan, bahwa ada tiga murid al-Samman yang diizinkan mengajar tarekat Sammaniyah. Yang paling h. 56 .

${ }^{9}$ Martin Van Bruinessen, Kitab Kuning; Pesantren dan Tarikat, (Bandung: Mizan, 1999),

${ }^{10}$ Azyumardi Azra, Jaringan Ulama ...., h. 139.

${ }^{11}$ Martin Van Bruinessen, Kitab Kuning ...., h.57. 
terkenal di antaranya adalah Siddiq bin Umar Khan al-Madani, guru Abd alSamad dan Muhammad Nafis. Atas permintaan Abd al-Samad, Syekh Siddiq telah menulis syarah tentang qasidah al-Nafhah al-Qudsiyah karangan al-Samman, yang merupakan sumber penting tentang ajaran tasawuf al-Samman. Belakangan ia menulis riwayat hidup gurunya pula yaitu al-Manaqib al-Kubra, yang di dalamnya banyak dibicarakan keajaiban-keajaiban al-Samman. Kitab manaqib ini kemudian beberapa kali diterjemahkan ke dalam bahasa Melayu dengan berbagai tambahan, yang pertama kali oleh M. Muhyiddin bin Syihabuddin al-Falimbani dengan judul Hikayat Syekh Muhammad Samman. ${ }^{12}$

Dalam Hikayat tersebut disebutkan sejumlah nama murid terkemuka Syekh al-Samman. Orang nusantara yang disebutkan Muhammad Arsyad al-Banjari, Abd al-Rahman al-Fatani dan tiga orang Palembang adalah: Syekh Abd al-Samad, Tuan Haji Ahmad dan dirinya sendiri Muhyiddin bin Syihabuddin. ${ }^{13}$

Tesis yang berkembang menyatakan, bahwa Muhammad Arsyad alBanjari adalah pembawa tarekat Sammaniyah ke Kalimantan Selatan. Meskipun data yang mendukung kesimpulan ini tidak begitu meyakinkan. Tidak seperti Muhammad Nafis al-Banjari, Muhammad Arsyad tidak menyebutkan bahwa dirinya mengamalkan tarekat tertentu. Meskipun dia menulis karya di bidang tasawuf, seperti Kanz al-Ma'rifah, namun tak ada penegasan, bahwa beliau menjadi khalifah atau pengamal tarekat tertentu. Sementara M. Nafis menegaskan dalam karyanya al-Durr al-Nafis, bahwa dia mengamalkan lima tarekat dalam kehidupannya, yaitu Qadiriyyah, Sattariyyah, Naqsyabandiyyah, Khalwatiyah dan Sammaniyah.$^{14}$

Meskipun Muhammad Arsyad al-Banjari tidak secara terbuka menyebut dirinya sebagai pengikut suatu tarekat seperti Sammaniyah. Namun dari buku Kanz al-Ma'rifah jelas bahwa beliau adalah pengikut suatu tarekat. Karena dalam sejarahnya diceritakan bahwa dia pernah berguru secara langsung kepada alSamman tentang tasawuf/tarekat. Oleh karena itu, dapat disimpulkan bahwa apa yang ditulisnya dalam kitab tersebut menggambarkan ajaran tarekat Sammaniyah .

K.H. Syarwani Abdan, seorang ulama besar keturunan Muhammad Arsyad al-Banjari di Bangil (w.1989 M). menegaskan bahwa al-Banjarilah yang

\footnotetext{
${ }^{12}$ Martin Van Bruinessen, Kitab Kuning ..., h. 58.

${ }^{13}$ Martin Van Bruinessen, Kitab Kuning ..., h. 58.

${ }^{14}$ Muhammad Nafis al-Banjari, al-Durr al-Nafis, (Singapora; al-Haramain li at-Tiba'ah wa an-Nasyr wa at-Tauzi, t.th), h. 38.
} 
memperkenalkan tarekat Sammaniyah di Kalimantan Selatan. Bahkan zuriatnya di Martapura menegaskan bahwa al-Banjari telah ditunjuk oleh gurunya alSamman sebagai khalifah tarekat Sammaniyah. Dengan gambaran tersebut, maka dapat disimpulkan bahwa beliau lah yang mengembangkan tarekat Sammaniyah di Tanah Banjar.

Ajaran tarekat Sammaniyah dapat dilihat pada bukunya Kanz al-Ma'rifah yang memperhatikan ajaran tasawuf/tarekat beliau. Dalam buku tersebut alBanjari menjelaskan tentang tata cara berzikir sebagai berikut: 1). Sebelum berzikir hendaklah mandi lebih dahulu, menghilangkan segala kotoran yang melekat pada badan; 2). Bersuci dari hadas dengan berwudhu; dan untuk membersihkan batin dengan banyak mengucap istigfar dan minta ampun kepada Tuhan; 3). Memakai pakaian putih dan berkhalwat di temapat yang sunyi; 4). Mengerjakan salat dua rakaat sekali salam untuk memohon taufik dan hidayah dari Allah swt.; 5). Duduk bersila sambil merendahkan diri kepada Allah dan menghadap ke kiblat dengan menghantarkan kedua telapak tangannya ke atas ke dua lutut-nya, seraya mengucap: Là ilaha, dengan mengiktikadkan bahwa keadaanku dan alam semesta ini wujudnya bukan wujud hakiki; 6). Selanjutnya baca: Illa Allah, dengan memejamkan kedua mata dan dengan mengiktikadkan dalam hati bahwa hanya Allah jualah wujud hakiki; 7). Akhir kata Allah, yaitu $H u$ dipanjangkan sedikit mengucapkannnya sambil meresapkan pandangan batinya, seakan-akan dirinya lenyap dan lenyap pula ingatan selain Allah, termasuk dirinya sendiri, sehingga hanya Allah Yang Wajibul Wujud. Pada saat seperti itu diharapkan turunnya jad₹̧bah (tarikan) dari Allah kepada-Nya. ${ }^{15}$

Demikian deskripsi tentang zikir dan tata caranya yang dikemukakan al-Banjari dalam risalah Kanz al-Makrifah, zikir ini jelas merupakan sejenis zikir tarekat, tetapi Al-Banjari tidak menegaskan tarekat apa yang dikemukakannya, karena tidak ada data yang menegaskan hal itu. Oleh karena itu, para pengkaji pemikiran al-Banjari di bidang tasawuf, berbedabeda menanggapi tentang tarekat yang diamalkan oleh al-Banjari. Ada yang berpendapat bahwa berdasarkan zikir tersebut, adalah tarekat Syadziliyah, ada pula yang mengatakan tarekat Sammaniyah. Menurut pengakuan juriyat al-Banjari zikir tersebut banyak diamalkan oleh masyarakat di daerah ini, sebagai mana yang diajarkan oleh K.H.M. Zaini Ghani (Guru Ijai) guru sekumpul di Martapura.

${ }^{15}$ Muhammad Arsyad al-Banjari, Kanz al-Ma'rifah (t.tp., t.pn., t.th.,) h. 2-3. 
Perbedaan tersebut berpangkal dari keragaman tarekat yang dianut oleh Syekh Muhammad al-Samman al-Madani, gurunya, yang menurut Martin Van Bruinessen pernah menganut pelbagai tarekat, yaitu: Khalwatiyah, Naqsyabandlyah, Qadiriyah, dan Syadziliyah. Dia dikenal sebagai tokoh yang mampu memadukan pelbagai teknik zikir dari tarekat-tarekat tersebut ditambah dengan susunannya sendiri. Dan kemungkinan inilah yang kemudian dikenal dengan tarekat Sammaniyah .

Dalam tarekat Sammaniyah, zikir yang digunakan melalui urutan-urutan sebagai berikut: dalam kitab al-Nafahat al-Ilabiyyah fi kayfiat Thariqat alMubammadiyah karya Syekh Muhammad al-Samman al-Madani disebutkan ada beberapa lafal zikir yang digunakan. Pertama, zikir dengan kalimat thaiyyibah "La ilaha Illa Allab". Kedua zikir dengan lafal yang datang dari anugerah ilahi pada lidahnya, seperti Allah, Allah, Hu, Hu, La-la, dan ah-ah. ${ }^{16}$ Disamping membaca ratib al-Samman. Zikir ini biasanya dilaksanakan setiap malam Jumat di masjid yang dilakukan secara bersama-sama sampai larut malam. Zikir tersebut biasanya diiringi bunyi-bunyian di bawah bimbingan seorang guru tarekat. ${ }^{17}$

Menurut versi tarekat Sammaniyah di Kalimantan Selatan zikir yang digunakan adalah zikir nafi isbat: La ilaha ilia Allab dibaca sebanyak 166 kali dan zikir ism zat yaitu Allah, Allab dibaca sebanyak 66 kali serta lafat bu, bu dibaca sebanyak 77 kali yang dilaksanakan setiap hari setelah salat Subuh dan salat Magrib. Zikir tarekat Sammaniyah yang digunakan di Kalimantan Selatan tersebut tampaknya cukup jauh berbeda dan lebih praktis dengan apa yang dicetuskan Syekh Muhammad al-Samman sebagaimana tertera di atas. Hal ini kemungkinan Syekh atau guru (mursyid) tarekat Sammaniyah di Kalimantan Selatan telah memodifikasi dan lebih menyesuaikan diri pada perkembangan dan kemajuan sekarang ini.

Bentuk zikir dalam tarekat Sammaniyah tampaknya juga dipengaruhi oleh bentuk lafal zikir yang ada dalam tarekat Khalwatiyah dan Khalwatiyah Qadiriyah karena bentuk zikirnya yang sampai kepada lafal "bu". Bahkan zikir tarekat Sammaniyah itu sama juga dengan tarekat Syadziliyah. ${ }^{18}$ Hal ini

${ }^{16}$ Zurkani Jahja, Hubungan Antara Tarekat Sammaniyah Dengan Tarekat yang lainnya. Makalah Seminar Bulanan Lembaga Kajian Keislaman dan Kemasyarakatan (LK3), Jumat, 19 April 2002.

${ }^{17}$ Tim, Ensikolopedia Islam Indonesia, (Jakarta: IAIN Syarif Hidayatullah, 1992), h. 842.

${ }^{18} \mathrm{Ahmad}$ al-Santanawi (et-al), Dairul al-Maarif al-Islamiyah, (Beirut: Dar al-Fikr, t.th), h.183. 
menimbulkan suatu pertanyaan apakah zikir tarekat Syadziliyah itu masih "murni" atau sudah tercampur dengan versi tarekat Sammaniyah . Karena pada umumnya tarekat Sammaniyah sampai saat itu dianggap sebagai tarekat yang berdiri sendiri dan tidak bercampur dengan tarekat Syadziliyah. Pendapat Karel Steenbrink itu perlu dipertanyakan, karena lafal zikir tarekat Syadziliyah itu tidak sama dengan apa yang ada pada tarekat Sammaniyah, yaitu tidak sampai kepada lafal, la, la, a, a, ab, ab atau bu, bu.

\section{Silsilah}

Silsilah tarekat Sammaniyah merupakan modifikasi yang dilakukan sendiri oleh Syekh Muhammad Samman terhadap metode-metode dzikir dan bacaan dari tarekat asli yang dianutnya, maka tentu saja silsilah ke atasnya akan mengikuti jalur tarekat asli tersebut. Silsilah ini yang digunakan menurut Syekh Abdul al-Samad al-Palimbani, salah seorang murid syekh Muhammad Samman adalah silsilah Khalwatiyah. ${ }^{19}$ Silsilah tersebut dapat disampaikan dalam tulisan ini yaitu: 1. Syekh Abdul al-Karim al-Samman al-Qadari al-Khalwati al-Madani, mengambil dari 2. Syekh Mustafa al-Bakri; mengambil dari 3. Syekh Abdul alLatif; mengambil dari 4. Syekh Mustafa Afandi al-Adranawi; mengambil dari 5. Syekh Ali Afandi Qurbasi; mengambil dari 6. Syekh Ismail al-Jarawi; mengambil dari 7. Syekh Muhyi al-Din al-Qasthuni. mengambil dari 8. Syekh Sa'ban al-Qasthamuni; mengambil dari 9. Syekh Halabi Sulthan al-Qura; mengambil dari 10. Bir Muhammad al-Azbakhani; mengambil dari 11. Syekh Abu Zakaria al-Syarwani al-Bakuni; mengambil dari 12. Bir Asdar al-Din; mengambil dari 13. Syekh Izzu al-Din; mengambil dari 14. Syekh Muhammad Mir al-Khalwati; mengambil dari 15. Bir Umar al-Khalwati; mengambil dari 16. saudaranya Muhammad al-Balisi; mengambil dari 17. Syekh Abi Ishaq Ibrahim al-Zahid al-Bakillani; mengambil dari 18. Syekh Jamal al-Ahwari; mengambil dari 19. Syekh Syihab al-Din al-Tibrizi; mengambil dari 20. Syekh Rukn al-Din Muhammad al-Najasi; mengambil dari 21. Syekh Quthub al-Din al-Abhari. mengambil dari 22. Syekh Abi al-Najib al-Suhrawardi; mengambil dari 23. Syekh Umar al-Bakri; mengambil dari 24. Syekh Wajih al-Din alQaqthi; mengambil dari 25. Syekh Muhammad al-Bakri; mengambil dari 26. Syekh Muhammad al-Dalnuri; mengambil dari 27. Syekh Muhammad alDainuri; mengambil dari 28. Syekh al-Junaid al-Baghdadi; mengambil dari 29. Syekh Sirri al-Saqathi; mengambil dari 30. Syekh Ma'ruf al-Karkhi; mengambil

${ }^{19}$ Abdul al-Samad al-Palimbani, Siar al-Salikin, (Beirut: Dar al-Kutub al-Islamiyah, t.th), juz. III, h. 39 . 
dari 31. Syekh Daud al-Tha'i; mengambil dari 32. Syekh Habib al-Ajami; mengambil dari 33. Syekh al-Hasan al-Bahhri. mengambil dari 34. Saidina Ali ibn Abi Thalib, r.a; mengambil dari 35. Nabi Muhammad saw; mengambil dari 36. Jibril, a.s.; mengambil dari 37. Allah swt. ${ }^{20}$

Murid-murid Muhammad Samman menurut M. Marwan adalah Syekh Abd. Ghani, Syekh Siddiq Umar Khan, Syekh Abu al-Abbas al-Tijani, Syekh Daud al-Fathani, Syekh Abdul al-Sammad al-Palimbani, Syekh Muhammad Nafis al-Banjari dan Syekh Muhammad Arsyad al-Banjari. ${ }^{21}$ Namun demikian, tidak semua murid Syekh Samman ini mengembangkan tarekat Sammaniyah di negerinya masing-masing. Di Indonesia menurut catatan Martin Van Bruinssen, dua tokoh yang sangat berperan dalam penyebaran ajaran tarekat ini adalah Syekh Abd al-Sammad al-Palimbani dan Syekh Muhammad Nafis alBanjari.

Syekh Muhammad Nafis al-Banjari mengaku telah mengamalkan salah satu tarekat, yaitu Sammaniyah, di antara gurunya adalah Shiddiq bin Umar Khan sebagai khalifah Syekh Samman yang juga pernah menjadi guru Abd alShamad.

Di sisi lain, dalam buku Ad-Durr al-Nafis, menyebutkan bahwa Muhammad Nafis terkait dengan tarekat Sammaniyah, karena ia pernah berguru dengan Abdullah bin Hajazi at-Syarqawi (w. 1812). Al-Syarqawi lebih dikenal sebagai ahli fiqh, namun ia juga seorang sufi. Dia adalah murid seorang tokoh tarekat Khalwatiyah yang terkenal dan bernama Malunud al-Kurdi yang menerima ijazah dari guru yang sama dengan Syekh al-Samman. ${ }^{22}$

Menurut Martin Van Bruissen, bahwa perkembangan tarekat Sammaniyah di Kalimantan Selatan sesudah Muhammad al-Nafis serta menurut beberapa sumber ulama di Kalimantan Selatan yang paling terkenal adalah Muhammad Arsyad al-Banjari. Ia pernah masuk tarekat Sammaniyah . ${ }^{23}$ Ada kemungkinan bahwa hal ini didukung dengan adanya kitabnya yang berjudul " Kanz al-Makrifah".

Tidak seperti Syekh Muhammad Nafis al-Banjari, Syekh Arsyad al-Banjari tidak menyebutkan bahwa dirinya mengamalkan tarekat tertentu.

${ }^{20}$ Siar al-Salikin ..., h. 39-40.

${ }^{21}$ Muhammad Marwan, Manakib Syekh Mubammad Samman al-Madani, (Kandangan: Sahabat, 1999), h. 67.

${ }^{22}$ Martin Van Bruinessen, Kitab Kuning, Pesantren dan Tarikat, Tradisi-Tradisi Islam di Indonesia, (Bandung: Mizan, 1999), h. 65.

${ }^{23}$ Martin Van Bruinessen, Kitab Kuning..., h. 66. 
Meskipun dia menulis karya di bidang tasawuf, seperti yang telah dikemukakan, namun tidak ada penegasan bahwa beliau menjadi pengamal tarekat tertentu. Sedangkan Muhammad Nafis al-Banjari ada menuliskan dalam karyanya alDurr al-Nafis, bahwa dia mengamalkan lima tarekat dalam kehidupannya yaitu: Qadiriyah, Satariyah, Naqsyabandiyah, Khalwatiyah dan Sammaniyah .

Berbeda dengan K.H. Syarwani Abdan, seorang ulama besar keturunan al-Banjari di Bangil (w. 1989 M), menegaskan bahwa al-Banjari memperkenalkan tarekat Sammaniyah (sebuah cabang dan tarekat Khalwatiyah) di Kalimantan Selatan. Bahkan zuriatnya di Martapura mengakui bahwa al-Banjari menjadi "khalifah" tarekat Sammaniyah itu dari gurunya di Madinah, yaitu Syekh Muhammad bin Abd al-Karim Samman al-Madani (w. $1771 \mathrm{M}$ ).

Terlepas dari siapa sebenarnya yang pertama kali membawa dan menyebarluaskan tarekat Sammaniyah di Kalimantan Selatan, perkembangannya tidaklah melebihi perkembangan tarekat-tarekat yang lain. Bahkan, dapat dikatakan perkembangannya kurang terdengar dan tidak jelas siapa sebenarnya yang menyebarkannya atau menjadi mursyîd-nya.

Berdasarkan hasil wawancara A. Athaillah dengan Haya Zabidi. ${ }^{24}$ Tarekat Sammaniyah baru mendapat sambutan yang luar biasa dan banyak pengikutnya dari masyarakat muslim Kalimantan Selatan, setelah Tuan Guru K.H. Zaini Abdul Ghani atau lebih pupoler dengan panggilan Guru Ijai dari Martapura mengenalkan dan meng-ijâzah-kan kepada murid-muridnya. Menurut salah seorang pengikut tarekat tersebut, Guru Ijai mulai mengenalkan dan mengjäazah-kan tarekat tersebut kepada masyarakat muslim Kalimantan Selatan, khususnya yang berasal dari Kabupaten Banjar pada tahun 1994 yang lalu.

Menurut keterangan, tarekat Sammaniyah yang telah diperkenalkan dan di-ijâzah-kan oleh Tuan Guru K.H. Zaini Abdul Ghani adalah tarekat yang sanadnya, tidak melalui Syekh Abd al-Shammad al-Palimbani dan Syekh Muhammad Nafis al-Banjari, tetapi melalui Syekh Muhammad Arsyad al-Banjari. Syekh Muhammad Arsyad menerima tarekat tersebut secara langsung dari Syekh Muhammad al-Samman, kemudian beliau mengajarkan kepada Syekh Syihabuddin, yang mengajarkan kepada Syekh Nawawi al-Bantani, kemudian mengajarkan kepada Syekh Zainuddin al-Sumbawi, yang mengajarkan kepada Syekh Abdullah al-Banjari, kemudian kepada Syekh H.

${ }^{24}$ Haya Zabidi adalah peserta Pengajian al-Rawdlah Sekumpul, Martapura dan pengikut tarikat Sammaniyah . Lihat A. Athaillah, Perkembangan Tarekat Sammaniyab di Kalimantan Selatan, Khazanah, Vol. III No. 02 Maret - April 2004, h. 225. 
Syarwani Abdan, yang terakhir ini kemudian mengajarkan kepada Tuan Guru H. Zaini Ghani. ${ }^{25}$

Agar eksistensi tarekat Sammaniyah dapat terpelihara, guru-guru tarekat tersebut berusaha mengembangkannya. K.H. Muhammad Zaini Ghani salah seorang ulama sufi yang paling populer di Kalimantan Selatan yang banyak mewariskan ajaran tarekat ini kepada murid-muridnya. Proses pewarisan ajaran tarekat Sammaniyah tersebut dilakukan K.H. Muhammad Zaini Ghani ada dengan pembaiatan secara khusus dan massal kepada pengikut pengajian yang ia asuh/pimpin. Hal ini merupakan karakteristik tersendiri dalam perkembangan tarekat Sammaniyah.

Jika diteliti asal aturan ajaran tarekat Sammaniyah maupun tarekat yang lainnya tidak pernah pembaiatan secara massal. Apabila seseorang yang ingin masuk suatu tarekat harus didahului dengan pembaiatan secara individual, berhadapan langsung antara murid dan guru (mursyid atau syekh) suatu terakat. Padahal pembaiatan itu sangat penting dalam suatu tarekat, karena pembaiatan merupakan janji seseorang kepada Allah untuk mentaati segala aturan dan menjauhi segala larangan-Nya. Agar janji tersebut betul-betul mendalam maka perlu disaksikan seorang yang alim, yaitu guru (mursyid). Jadi, baiat sebenarnya bukanlah janji seseorang kepada guru, tetapi janji kepada Allah. Fungsi guru dalam berbaiat tersebut hanyalah sebagai saksi. Kalau ada saksi janji itu akan selalu diingat oleh yang melakukannya.

Dalam mengembangkan tarekat Sammaniyah di Kalimantan Selatan, K.H. Muhammad Zaini Ghani telah mentransfer ajaran tarekat Sammaniyah kepada murid-muridnya, di antaranya adalah. Pertama, K.H.M. Syukeri Unus, kelahiran. Hulu Sungai Utara (Amuntai) pada tanggal 5 Oktober $1948^{26}$ ia masuk tarekat Sammaniyah tahun 1970 an melalui K.H. Muhammad Zaini Ghani dengan cara yang khusus, karena pada tahun tersebut ia membuka majelis taklim (pengajian agama) yang sekaligus menyebarkan tarekat Sammaniyah. Pengajian tersebut dilaksanakan setiap pagi hari Rabu, Kamis dan Minggu, dan pada malam Rabu, Sabtu dan Minggu. Peserta pengajian itu berjumlah kurang lebih 2000 orang. Kebanyakan pesertanya adalah kaum lakilaki, kecuali pengajian pada malam Rabu, pesertanya terdiri dari kaum laki-laki dan perempuan.

${ }^{25}$ A. Athaillah, Perkembangan ..., h. 225

${ }^{26}$ K.H. M. Syukeri Unus berpendidikan Sekolah Dasar, Sekolah Menangah Pertama (SMP), Madrasah Tsanawiyah dan Madrasah Aliyah Darussamalam. Ia bermarwai dengan KH. Muhammad Zaini Ghani (Guru Ijai) karena isterinya bersaudara. 
Kedua, K.H. Sofyan Noor bin H. Ahmad Sya'rani yang dilahirkan di Martapura Kabupaten Banjar pada tanggal 20 Oktober 1956, ${ }^{27}$ ia masuk tarekat Sammaniyah pada tahun 1980 an melalui K.H. Muhammad Zaini Ghani secara massal. Dalam mengembangkan ajaran tarekat Sammaniyah, ia membuka pengajian yang dilaksanakan setiap malam Selasa (setelah Salat Magrib) di Kelurahan Keraton Martapura. Pengajian tersebut mendapat sambutan dan perhatian masyarakat Martapura baik laki-laki maupun perempuan. Pesertanya mencapai kurang lebih 1.500 orang.

Ketiga, KH. Syamsuri bin H. Muhrid yang dilahirkan di Martapura pada tahun $1959,{ }^{28}$ ia masuk tarekat Sammaniyah pada tahun 1980 an melalui K.H. Muhammad Zaini Ghani dengan cara khusus (individual). Dalam mengembangkan ajaran tarekat yang dianutnya, ia telah membuka pengajian agama (majelis taklim) yang dilaksanakan setiap malam Selasa setelah salat Isya di Kelurahan Pasayangan. Peserta pengajian tersebut berjumlah kurang lebih 1000 orang yang terdiri dari laki-laki dan perempuan.

Keempat, K.H. Munawar Gazali yang dilahirkan pada tahun 1972 di Martapura. ${ }^{29}$ ia masuk tarekat Sammaniyah melalui ayahnya sendiri yaitu Guru H. Gazali yang mengambil dari K.H. Syarwani Abdan dari Bangil. Ia juga membuka pengajian agama (majelis taklim) yang diselenggarakan setiap pagi dan sore hari di Kampung Melayu Martapura, dengan jumlah pengikutnya kurang lebih 1000 orang baik laki-laki maupun perempuan.

Keempat murid (muqadam) dari tarekat Sammaniyah tersebut adalah para ulama yang cukup kharismatik di masyarakat Martapura. Dengan cara tersebut berkembanglah tarekat Sammaniyah dengan pesat. Di samping itu, masyarakat Martapura cukup antusias masuk dan mengamalkan ajaran tarekat Sammaniyah. Hal itu dapat dilihat dari bertambahnya pengikut tarekat Sammaniyah di Martapura dan sekitarnya, yang sekarang berjumlah kurang lebih 10.000 orang yang terdiri dari laki-laki maupun perempuan, dengan berbagai latar belakang pendidikan dan strata sosial masyarakat, seperti

${ }^{27}$ K.H. Sofyan Noor adalah seorang guru agama dan berpendidikan Madrasah Ibtidaiyah, Madrasah Tsanawiyah dan Madrasah Aliyah Pondok Pesantren Darussalam.

${ }^{28}$ K.H. Syamsuri adalah seorang guru agama dan berpendidikan Madrasah Ibtidaiyah, Madrasah Tsanawiyah dan Madrasah Aliyah Pondok Pesantren Darussalam Martapura.

${ }^{29} \mathrm{KH}$. Munawar Gazali adalah seorang guru agama dan berpendidikan Madrasah Ibtidaiyah, Madrasah Tsanawiyah dan Madrasah Aliyah Pondok Pesantren Darussalam Martapura. 
pengusaha, pegawai negeri, tokoh-tokoh agama, pedagang, dan petani, baik yang datang dari perkotaan maupun dari perdesaan. Namun yang terbanyak adalah dari golongan petani. ${ }^{30}$

Perkembangan tersebut juga dipengaruhi oleh perhatian masyarakat Kalimantan Selatan terhadap ilmu-ilmu keagamaan terutama ilmu-ilmu kerohanian atau olah batin. Di mana umumnya penduduk Kalimantan Selatan penganut paham Ahl al-Sunnah wal Jamaah atau beraliran Suni. Di samping itu, masyarakat Banjar sangat menghormati kiai atau ulama dan selalu memegang apa yang yang difatwakan kiai atau ulama tersebut.

\section{Kitab yang Digunakan}

Ada beberapa kitab yang sering menjadi rujukan dalam pengamalan tarekat ini, di antaranya adalah:

a. Manâqib Walî Allâh Ta'âla al-Syaikh Muhammad ibn 'Abd al-Karîm al-

Qâdiry al-Hasanî al-Sammân al-Madanî

buku ini ditulis oleh K.H. Muhammad Zaini Ghani dengan menggunakan huruf Arab Melayu dituis dengan tangan setebal 24 halaman, yang diterbitkan oleh Mathba'ah Raudhah Banjarbaru. Tidak diketahui secara pasti kapan kitab ini ditulis, namun dari sumber yang didapat, diperkirakan buku ini sudah ada sejak tahun $1996 .{ }^{31}$

Isi kitab adalah, pertama Pendahuluan atau muqaddimah. Kedua inti dari manakib Syekh Sammân yang membicarakan tentang tabiat (kepribadian) Syekh Sammân. Ketiga tentang wasiat-wasiat Syekh Sammân. Pada kitab ini juga disebutkan bahwa Syekh Sammân lahir pada tahun 1132 H di Madinah dan wafat pada tahun 1189 H di Madinah, dan dikuburkan di Baqî’ berdekatan dengan pekuburan isteri Rasulullah saw. Keempat disebutkan bahwa orang yang membaca manakib Syekh Sammân setiap tahun sekali bersama orang banyak dengan disertai membaca al-Qur'an, tahlil, dan bersedekah sekadar kemampuan, kemudian pahalanya dihadiahkan kepada Syekh Sayyid Muhammad Sammân, dan lebih baik lagi dilaksanakan pada hari wafatnya, maka Allah akan diluaskan rezekinya, dan akan tercapai semua hajatnyadunia dan akhirat. Kelima, do'a dan kemudian dilanjutkan dengan tawassulât alSammaniyah serta diakhiri dengan dua sanad K. H. Muhammad Zaini Ghani yang berisi rangkaian guru yang menghubungkan beliau dengan Syekh

\footnotetext{
${ }^{30}$ Keterangan dari beberapa orang. Peserta Pengajian al-Rawdlah.

${ }^{31}$ Lihat Syahriansyah, dkk., Ulama Banjar ..., h. 30.
} 
Sammân. Jalur pertama dari Muhammad Amîn al-Kutbî dan jalur kedua dari Syekh Muhammad Syarwanî'Abdân al-Banjarî. ${ }^{32}$

b. Al-Risâlah al-Nûrâniyyah fi Syarhi al-Tawassulât al-Sammaniyah

Kitab ini ditulis oleh K.H. Muhammad Zaini Ghani yang ditulis dengan menggunakan Bahasa Arab, setebal 57 halaman, yang diterbitkan oleh Mathba'ah Raudhah Banjarbaru pada tahun $1995 .^{33}$ Kitab Al-Risâlab alNûrâniyyah ini terdiri dari empat bagian: (1) Pendahuluan, (2) Tawassul Sammâniyyah, (3) Syarh Tawassul Sammâniyyah (4) Penutup.

Pada bagian pendahuluan disebutkan mengenai kebolehan bertawassul, istighatsah dan memohon syafa'at kepada Nabi Muhammad saw, para Nabi dan Rasul lainnya, para wali Allah, dan orang-orang shaleh menurut mazhab Ahlus Sunnah wal Jama'ah. Bagian kedua berisi tentang tawassul sammâniyyah. Tawassul Sammaniyah disebut juga dengan "Jâliyat al-Kurabi wa Munilat alArabi". Bagian ketiga adalah syarah dari tawassul Sammaniyah, yakni penjelasan mengenai makna yang terkandung dalam tiap kata atau kalimat dalam tawasul Sammaniyah tersebut. Bagian keempat adalah penutup, pada bagian ini disebutkan bahwa ini merupakan akhir yang mudah daripada anugerah Allah swt. diiringi dengan ungkapan "semoga Allah menjadikannya ikhlas bagi wajah-Nya yang mulia dan simpanan serta wasilah bagi mencapai nikmat yang abadi". Kemudian ditutup dengan shalawat Nabi .

Dinyatakan dalam buku ini, selesai penulisannya pada hari Jum'at, 6 Rabî’ul Awwal 1416 H. oleh Abu Muhammad Amîn Badalî al-Hâjj Muhammad Zainî bin 'Abd al-Ghanî al-Banjarî, dengan disertai tanda tangan beliau. Kitab ini disertai lampiran, berupa ijazah, penulis, K.H. Muhammad Zaini Ghani, mengijazahkan seluruh isi dari risalah ini untuk diketahui dan diamalkan agar memperoleh manfaat dan ilmu, yang semuanya diambil dari 'Arif billâh alSayyid Muhammad bin 'Abd al-Karîm al-Qâdirî al-Hasanî al-Syahîr bi alSammân al-Madanî yang diijazahkan dari guru beliau al-Sayyid Muhammad bin Amîn al-Kutbî al-Makkî.

c. Al-Imdâd fî Aurâd Ahl al-Widâd

Kitab ini diterbitkan oleh PT. Al-Zahra Banjarbaru, dan mengalami beberapa kali cetakan. Cetakan pertama pada tahun 1426 H (2005 M) dan cetakan keenam tahun 1430 H. (2009 M). Isi kitab 479 halaman dengan cover lux yang ditulis dengan bahasa Arab dan beberapa penjelasannya dengan Arab Melayu. Sebagaimana judulnya Al-Imdâd fì Aurâd Abl al-Widâd, yang berarti

\footnotetext{
${ }^{32}$ Syahriansyah, dkk., Ulama Banjar ..., h. 30
}

${ }^{33}$ Syahriansyah, dkk., Ulama Banjar ..., h. 75. 
penolong dalam wirid-wirid orang ahli dalam kasih sayang, isinya adalah berupa amalan-amalan, ataupun wirid yang diamalkan dalam kehidupan sehari-hari.

Secara garis besar kitab dapat diklasifikasikan menjadi: (1) Bacaan yang diambil dari ayat al-Qur'an seperti; surah al-Kahfi, surah Yâsîn, surah al-Fath, surat al-Wâqi'ah, surah al-Mulk; (2) Amaliyah Thâriqat berupa wirid, râtib, qashîdah, dan tawassulât, seperti: Wird al-Lathîf, Wird al-Sukrân, Râtib alHaddâd, Râtib al 'Aththâs, Hizb al-Bahr, Hizb al-Nashr, Hizb al-Nawawî, Bacaan yang berupa qashîdah, seperti: Qahîdah al-Burdah, Qashidah li alHabîb Abî Bakr al-'Idrûs, Qashîdah li al-Habîb 'Abd Allâh bin Husîn. Sedangkan yang berupa tawasul adalah: Tawasulât al-Sammaniyah, Khawâtim Khawâjakan (sesudah membaca khawâtim khawâjakan dilanjutkan dengan bacaan tawassul Syaikhinâ Muhammad Amîn Kutbî), (3) Wirid, doa, istighfar, shalawat. Amalan berupa wirid, seperti: wirid shalat lima waktu. Doa-doa yang terdapat dalam al-Imdâd ini seperti: doa khatam al-Qur'an, doa salamat, doa untuk keturunan Sayyidinâ 'Alî Zain al-'Abidîn, Doa untuk zuriat al-Habîb 'Idrûs bin 'Umar al-Habsyî, doa orang tua kepada anaknya, doa birr al-walidain, doa supaya terbayar hutang, bacaan agar dimudahkan pergi haji, doa tolak bala, doa supaya jangan diganggu iblis, doa arwah, dan doa khatam majelis. Amalan yang berupa istighfar, seperti: istighfar yang besar (al-'azhîm), istighfar masybûr yang dibaca pada pagi dan sore. Sedangkan yang berupa shalawat, seperti: shalawat obat penyakit li al-Habîb Abi Bakr bin Sâlim, shalawat 'å̧hîm, shalawat kâmilah. (4) Kaifiyat (tata-cara) pelaksanaan ibadah sunnah, seperti: kaifiyat shalat wudhu, kaifiyat shalat taubat, kaifiyat shalat sunnat shubuh, kaifiyat shalat isyraq, kaifiyat shalat dhuha, kaifiyat shalat istikharah, kaifiyat shalat hajat, kaifiyat sembahyang hadiah, dan kaifiyat shalat tasbih. (5) Kaifiyat pelaksanaan ibadah yang berhubungan dengan kehidupan sosial, seperti: kaifiyah acara nikah, kaifiyat tasmiyah (pemberian nama anak), kaifiyat shalat jenazah, kaifiyat tahlîl, kaifiyat bahîlah, kaifiyat ziarah, kaifiyat shalat tarawih, dan kaifiyat shalat witir. Di samping itu juga dimasukkan bacaan seperti: ma'âsyir al-Jum'at dan dua hari raya. ${ }^{34}$

\section{Motivasi Masyarakat Masuk Tarekat Sammaniyah}

Ada beberapa alasan seseorang tertarik menjadi pengikut pengajian tarekat Sammaniyah, di antaranya, yaitu: Pertama, ingin mendapat ilmu pengetahuan agama. Masyarakat yang datang ke pengajian tarekat Sammaniyah yang berlokasi di Komplek Sekumpul bertujuan untuk menuntut dan menambah ilmu pengetahuan agama, karena mereka merasa pengetahuan yang

${ }^{34}$ Syahriansyah, dkk., Ulama Banjar ..., h. 76-77. 
dimiliki masih kurang. Pengikut tarekat ini sadar bahwa menuntut ilmu agama itu diwajibkan oleh ajaran Islam.

Pengikut tarekat Sammaniyah mengaku, di setiap kali mengikuti pengajian memberikan kesadaran diri, menambah kecintaan terhadap ilmu pengetahuan agama. Kesadaran mereka itu secara tidak langsung menumbuhkan sifat tanggung jawab untuk selalu mengabdikan diri pada agama dan ntuk menuntut ilmu pengetahuan. Dengan semikian tanpa diperintahkan dengan sendirinya keinginan untuk menghadiri pengajian itu selalu muncul.

Pengajian dengan Tarekat Sammaniyah yang dilaksanakan di Martapura Kabupaten Banjar yang dipimpin oleh K.H. Muhammad Zaini Ghani merupakan wahana mengembangkan ajaran Islam di masyarakat. Masyarakat tertarik mengikut pengajian tarekat Sammaniyah di Komplek Sekumpul ini, mengingat penyampaian ajaran Islam dengan bahasa yang sederhana dan mudah dimengerti. Materi yang disampaikan dalam pengajian itu berkaitan dengan realitas kehidupan sehari-hari, yaitu tentang akidah atau tauhid, fikih, akhlak, tasawuf, dan juga tafsir.

Pengikut tarekat Sammaniyah tampaknya menggunakan momentum pengajian itu sebagai sarana untuk pensucian dan pendekatan diri kepada Allah. Karena itu, mereka pergi menuntut ilmu pengetahuan dengan niat yang ikhlas. Keikhlasan ini mendorong mereka untuk berkorban, baik waktu, tenaga maupun materi dengan tujuan dapat mengikuti pengajian ini. Meskipun tempat tinggal sebagian besar mereka, relatif jauh dari tempat pengajian itu, mereka tetap berupaya untuk dapat datang, selama mereka bisa. ${ }^{35}$

Kedua, ingin mendapatkan ketenangan batin. Masyarakat yang mengikuti pengajian tarekat Sammaniyah di komplek Sekumpul merasakan ketenangan batin. Ketentraman batin ini selalu mereka rasakan ketika datang dan mengikuti pengajian tersebut. Ketenangan batin dan ketentraman dalam hidup merupakan dambaan setiap orang.

Amalan zikir erat kaitannya dengan ketenangan. Dalam Islam, seorang muslim diperintahkan untuk selalu berzikir dan mengingat Allah Pencipta alam semesta. Dengan terus ingat kepada Allah, mengakui akan kebesaran serta rahmat dan kasih sayang Allah niscaya seseorang tidak akan mudah putus asa. Sebaliknya, dengan selalu mengingat Allah seseorang akan menjadi tenang dan selalu merasa optimis dalam meniti kehidupan di dunia. Dalam pengajian ini, guru Ijai selalu mengajak jamaahnya berzikir. Dengan kemampuannya, ia

${ }^{35}$ A. Fauzan Saleh, Tarekat Sammaniyah di Kabupaten Banjar Kalimantan Selatan, Tesis, (Banjarmasin: Program Pascasarjana IAIN Antasari, 2004), h. 111. 
membawa pengikut tarekat ke dalam suasana dalam dalam zikrullah, para pengikut pun merasa antusias untuk selalu mengikuti pengajian tersebut. Keikhlasan dan antusiasnya mereka mengikuti pengajian itu membuat pengajian itu selalu semarak.

Para pengikut tarekat ini meyakini, selain ketenangan mereka juga mendapatkan rezeki yang selalu mengalir. Ini terbukti pada muqaddam tarekat ini, meskipun tidak bekerja namun mereka tetap kaya. Mereka dapat membangun majelis taklim dan rumah karena bertawakkal kepada Allah dan menerima sumbangan suka rela kepada pengikut tarekat itu sendiri. Sebab takdir yang telah dibuat Allah pasti di terima. Keputusan Allah tidak berubah, sudah digariskan dalam labul mahfud. Guru (mursyid) tarekat Sammaniyah mengatakan, dalam urusan rezeki seharusnya manusia bertawakkal kepada Allah. Sebab Allah menjamin hambanya untuk bekal dan kepentingan ibadat. Hal ini didasarkan firman Allah pada surat at-Talaq/65: 3 yang artinya, ... dan Barangsiapa yang bertawakkal kepada Allah niscaya Allah akan mencukupkan (keperluan)nya...

Seorang guru (mursyid) sangat yakin bahwa rezeki itu dijamin oleh Allah swt. tanpa berusaha mencarinya, itulah yang mereka lakukan pada saat ini. Mereka tidak bekerja dalam arti zahir tetapi berusaha dalam beribadat atau batin. Keyakinan yang mantap dan tawakkal kepada Allah swt. itu membuat mereka hidup dengan tenang, bahagia, dan mendapat rezeki sebagaimana kebanyakan orang yang bekerja. Mereka bisa membangun majelis taklim untuk tempat pengajian (zawiyah) maupun rumah milik mereka.

Ketiga, ingin beribadat. Masyarakat yang selalu mengikuti pengajian tarekat Sammaniyah, bukan saja dimotivasi oleh keinginan untuk menuntut ilmu dan mendapatkan ketenangan batin, tetapi juga dimotivasi oleh keinginan untuk beribadat. Beribadat dimaksud adalah salat berjamaah, membaca wirid, dan membaca syair Maulud al-Habsyi. Mareka merasa bahwa beribadat di Komplek Sekumpul bersama dengan pengikut lainnya membuat hati lebih khusyuk. $^{36}$

Hal itu tampaknya didukung oleh suasana di lingkungan Komplek Sekumpul yang terasa aman dan penuh persaudaraan (ukhuwah Islamiyah). Suasana damai terasa menyelimuti hati setiap pengikut yang memasuki kawasan itu. Bahkan, pendatang baru pun yang datang ke sana pada saat pengajian akan merasakan suasana aman dan damai. Dalam Islam, umatnya ditekankan untuk melakukan salat fardu secara berjamaah dijanjikan mendapat pahala yang

${ }^{36}$ A. Fauzan Saleh, Tarekat Sammaniyah ..., h. 112. 
berlipat ganda. Hal ini sesuai dengan Sabda Rasulullah saw. yang artinya, "Shalat berjamaah itu lebih utama dari shalat sendirian sebanyak 27 kali" (HR. Bukhari). ${ }^{37}$

Dorongan untuk beribadat bersama-sama dengan orang-orang saleh, khususnya ulama yang menjadi idola, melahirkan keinginan yang menggebu untuk selalu datang dan mengikuti rangkaian pengajian. Dari tiga jenis motif yang terdiri dari motif biogenetis, motif sosiogenetis, dan motif teogenetis, motif teogenetislah yang berhubungan erat dengan Tuhan atau yang bersifat supranatural. ${ }^{38}$

Keempat, ingin mendapat berkah. Berdasarkan observasi yang ditopang dengan wawancara, ternyata mendapat berkah dari guru adalah salah satu motif yang mendorong para jamaah mengikuti pengajian agama (tarekat Sammaniyah ) di Komplek Sekumpul. Kepercayaan akan mendapat berkah dari seorang tuan guru sangat kuat dalam diri para jamaah. Hal ini disebabkan, K.H. Muhammad Zaini Ghani merupakan seorang ulama yang menurut mereka sangat dekat kepada Allah. Karena itu tidak mengherankan bila mereka menganggap ia sebagai salah seorang aulia Allah.

Keinginan untuk mendapatkan berkah dari tuan guru sangat erat kaitannya dengan kepercayaan bahwa orang-orang saleh itu membawa keberuntungan bila ditemani. Keberuntungan itu, ada kalanya berkaitan dengan bisnis, dan adakalanya berkaitan dengan suasana kehidupan sehari-hari.

\section{Penutup}

Perkembangan tasawuf terutama tarekat Sammaniyah di Tanah Banjar memiliki akar sejarah yang cukup panjang dan telah menjadi bagian hidup dari masyarakat Banjar itu sendiri. Karenanya mulai dari masuknya Islam ke wilayah ini, sampai masa perjuangan fisik hingga pembangunan sekarang diyakini bahwa tasawuf dan tarekat tetap eksis dan survive dalam menjaga kerohanian masyarakat. Disamping itu hal yang lebih penting dan menarik lagi untuk menjadi bahan renungan adalah bahwa informasi yang berkembang dan data sejarah yang berserakan tentang keberadaan atau jejak sejarah perkembangan tasawuf atau tarekat Sammaniyah di Kalimantan Selatan pada masyarakat

\footnotetext{
${ }^{37}$ Abi Abdillah Muhammad Ibnu Ismail Bukhari, Sabih Bukhari, (Indonesia: Daru Ahya Maktabatil Arabiyah, t.th). h. 119

${ }^{38}$ W.A. Gerungan, Psikologi Sosial, (Bandung: Eresco, 1986), h. 162-163
} 
Banjar khususnya perlu untuk dikaji dan diteliti kembali secara lebih mendalam dan konfrehensif.

\section{Daftar Pustaka}

Arsyad al-Banjari, Muhammad, Kanz al-Ma'rifah, t.tp., t.pn., t.th.

Athaillah, A., Perkembangan Tarekat Sammaniyah di Kalimantan Selatan, Khazanah, Vol. III No. 02 Maret - April 2004.

Azra, Azyumardi, Jaringan Ulama Timur Tengah dan Kepulauan Nusantara Abad XVII dan XVIII, Bandung, Mizan, 1994.

Bruinessen, Martin Van, Kitab Kuning; Pesantren dan Tarikat, Bandung, Mizan, 1999.

Bukhari, Abi Abdillah Muhammad Ibnu Ismail, Sabib Bukhari, Indonesia, Darul Ahya Maktabatil Arabiyah, t.th.

Gerungan, W.A., Psikologi Sosial, Bandung: Eresco, 1986.

Jahja, Zurkani, Hubungan Antara Tarekat Sammaniyah Dengan Tarekat yang lainnya. Makalah Seminar Bulanan Lembaga Kajian Keislaman dan Kemasyarakatan (LK3), Jumat, 19 April 2002.

Marwan, Muhammad, Manakib Syekh Mubammad Samman al-Madani, Kandangan, Sahabat, 1999.

Saleh, A. Fauzan., Tarekat Sammaniyah di Kabupaten Banjar Kalimantan Selatan, Tesis, Banjarmasin, Program Pascasarjana IAIN Antasari, 2004.

al-Santanawi, Ahmad (et-al), Dairul al-Maarif al-Islamiyah, Beirut, Dar al-Fikr, t.th.

Syahriansyah, dkk., Profil Tarikat di Kalimantan Selatan, Banjarmasin, Antasari Press, 2009.

-------, Ulama Banjar dan Karya-Karyanya, K.H. Abdul Hamid Karim, K.H. Zaini Gani dan K.H. Muhammad Bakheit, Banjarmasin, Puslit IAIN Antasari, 2009.

Tim, Ensikolopedia Islam Indonesia, Jakarta, IAIN Syarif Hidayatullah, 1992. 